\title{
A REGIONÁLIS POLITIKA VÁLASZÚTON (EURÓPAI PERSPEKTÍVÁK)
}

Albrechts, L. - Moulaert, F. Roberts, P. - Swyngedouw, E. (szerk.) (1989)

Regional Policy at Crossroads (European perspectives)

Jessica Kingley Publishers Ltd. London, 199 o.

1987. április 22-24. között egy belga kisvárosban, Leuvenben, $A$ regionális politika válaszúton: a regionális tervezés és fejlesztés új perspektívái címmel nemzetközi konferenciát rendeztek. Az elhangzott elôadásokból némi átdolgozás után 11 került kiválogatásra.

Ez a kiadvány elsõként kísérli meg jelezni azokat a változásokat, amelyek a regionális politikát válaszútra késztetik, illetve igyekszik megfogalmazni a regionális politikával szemben támasztott jövốbeni elvárásokat.

A két belga (Swyngedouw, Albrechts), egy francia (Moulaert) és egy angol (Roberts) tudós által szerkesztett mú (a prológuson és az epilóguson kívül) hármas tagolású. Tartalmát tekintve azonban kettôs felosztású. Az egyik csoportba tartozók a regionális politika analízisével és leírásával vannak kapcsolatban, de azt vagy makroszinten (Kowalski, Allen), vagy mikroszinten (Courlet), vagy a két szemléletet érdekes módon ötvözve (Albrechts és Swyngedouw) közelítik meg. A közremũködốk másik fele (Martin, Martinelli, Österland) a napjainkban és az 1970-es évek közepe óta zajló regionális változások mögötti tényezốkkel foglalkoznak elsôdlegesen.

A szerkesztốk által írt elốszó, $A$ regionális politika és fejlesztés újperspektívái az 1900-as években egyfelôl a kötet alapvetổ céljait nevezi meg:

Az egyenlốtlen regionális fejlôdés jelenlegi magyarázata érvényességének felülvizsgálata, és azoknak az újonnan felbukkanó irányoknak, trendeknek a felbecsülése, amelyek Európa régióinak jövổbeni sorsát alakíthatják;
Olyan politikai modellek megalkotása, amelyek egyaránt tükrözik az EGK-nak és az egyes régióknak a válságfolyamatokra adott válaszait.

Az elổszó szerzôi másfelốl vázolják a kötet tematikus súlypontjait:

A regionális fejlesztési folyamatok perspektívái;

Politikai feladatok és megvalósításuk;

A nemzetközi, a nemzeti és a helyi folyamatok közötti kölcsönhatás.

Az elsố témakörhöz négy tanulmány tartozik. Martinelli a termelô szolgáltatások, az innováció és a regionális politika közötti összefüggéseket kutatta Olaszország fejletlen délvidékén. Az elmúlt évtizedben ugyanis mind a közgazdászok, mind a tervezési szakemberek nagy figyelmet fordítottak ezekre a tényezôkre. Bebizonyosodott, hogy döntố elemei a területi fejlesztésnek, az üzemek és régiók közötti versenyképességnek. Megoszlásuk térben egyenlốtlen, többnyire a magterületeken koncentrálódnak, így a perifériák ebből a szempontból szintén hátrányba kerülnek. A Mezzogiorno is egyike ezen kevésbé fejlett térségeknek, amelynek a háború utáni mintegy 35 évig tartó aktív állami beavatkozás ellenére sem sikerült behoznia a lemaradást. A szolgáltatásban dolgozók aránya $(48 \%)$ tøvábbra is alacsonyabb az országos átlagnál (51\%), az iparszerkezet viszonylag fejletlen és duális jellegú. Mindez az olasz regionális politika megváltozását sürgette. Míg korábban a pénzügyi ösztönzők jelentették a ,,nemzeti", regionális politika legfốbb eszközét, addig 
napjainkra a szolgáltatások fejlesztése és az innovációk terjedésének támogatása került előtérbe. Ez egyúttal az intézményi struktúra átszervezôdését, a központi beavatkozások háttérbe szorulását és a regionális kormányzatok jelentôségének erốsödését vonta maga után.

Martin a regionális , átstruktúrálódás' új gazdasági, politikai folyamatairól számol be a brit tapasztalatok alapján. A II. világháború utáni évtizedekben az egymást követố kormányok olyan regionális politikát folytattak, amelynek legfốbb célja a területi egyenlốtlenségek mérséklése volt. Az 1970-es évekre nyilvánvalóvá vált, hogy a regionális politika céljait és eszközeit felül kell vizsgálni, újra kell értékelni. Az ekkor kezdốdố gazdasági, politikai változások jóval mélyebben érintették Nagy-Britanniát, mint Nyugat-Európa más országait. Okai között szerepel az ipari üzemek számának csökkentése, a technológiai innováció, a gazdaság tercier szektorának megújulása és az állami intervenció módjainak újradefiniálása. Az író ezt a radikál is fordulatot érti az ,,átstruktúrálódás" folyamatán. Az átalakulásra, átszervezốdésre orientált regionális politika lényeges eszközei a következők:

A helyi gazdaság fejlesztése magas technológiájú iparra és innovációs tevékenységre alapozva;

Az elavult iparágak és üzemek , újraélesztése", modernizálása;

A piacképes magánszolgáltatások kiterjesztése és bôvítése;

A munkaerố technikai kvalifikációjának, szakképzettségének változatosabbá tétele és további emelése;

Regionális és helyi pénzügyi piacok létrehozása, tốke és beruházási alapok biztosítása .

$\mathrm{Az}$ átalakított regionális politika sikere nagymértékben függ majd attól, hogy a nemzeti politika mennyiben tud támaszkodni és ,válaszolni" rá.
A két holland szakember - Janssen és von Hoogstraten - Az új infrastruktúra és a regionális fejlesztés közötti kapcsolatot vizsgálta. Még ma is sok olyan ország van, ahol a regionális fejlesztési politika legdöntôbb eleme az infrastruktúra fejlesztése. Számos tanulmány értékelése után viszont a szerzópáros azt a következtetést vonja le, hogy az infrastruktúrális ellátás nem vezet szükségszerûen regionális fejlôdéshez, illetve regionális kiegyenlítốdéshez. Ezt igazolják a hagyományos infrastruktúra-politikával összefüggésben felmerült problémák is. Például, hogy az infrastruktúrának vannak olyan részei, amelyek kevésbé vonzók az ipartelepítés szempontjából; hogy az infrastrukturális beruházásoknak szelektív és elốre nem látható hatásai lehetnek; hogy a periférikus területek infrastrukturális ellátásának javítására irányuló beruházások inkább fokozzák a regionális feszültségeket. Éppen ezért van szükség az ,újj" infrastruktúraértelmezésre, amelyen a szerzők - a sokféle megközelítés ellenére - "... nemcsak a valóban új információs és kommunikációs rendszereket értik, hanem a régi infrastruktúra megújhodását is". Véleményük szerint az , „új” infrastruktúra egyaránt képes fokozni a regionális gazdaság produktív kapacitását és mérsékelni a regionális egyenlôtlenségeket. Ehhez azonban szakítani kell a regionális és infrastrukturális politika tradicionális elméleteivel.

A II. világháború után a fejlett tôkés országok regionális politikája elsốsorban a térbeli különbségek csökkentését célozta. Az 1960-as évek végén, az 1970-es évek elején azonban ez a politika válságba került. A legtöbb országban az átmenet , ,.. a , fordizmusból' a fejlesztés egy ,flexibilisebb' típusába..." nemcsak új gondokat vetett fel, hanem egyúttal új kihivást is jelentett. Albrechts és Swyngedouw hangsúlyozza, hogy a fejlesztés módjában bekövetkezố strukturális átala- 
Tér és Társadalom 4. évf. 1990/3-4. 191-201. p.

kulások a tervezési menettôl és a tervezési gyakorlattól egyaránt új elméleti, tartalmi és módszertani megközelítést igényelnek. A jövôben egy tagoltabb, több tényezôre épülổ (nemcsak pénzügyi ösztönzókre támaszkodó), az eltérō megközelítéseket (top-down-t és bottom-up-t) jól ötvözố regionális politikára lesz szükség. Az elóbbi olyan szerkezeti, gazdasági és politikai változásokat céloz, amely magába foglalja a tervezést és a beruházási döntések orientációját éppúgy, mint a redisztribúciós programok végrehajtását. Az utóbbi eszközei az ún. ,,helyi adottságok” jelentôségének megerôsítésére, és racionális hasznosításukra irányulnak.

A második fổ fejezetet két dolgozat alkotja. Kowalski a megnagyobbodott Közösség jelenlegi nehézségeit és jövốbeni feladatait vázolja. A tagállamok számának megduplázódása hatról tizenkettốre 13 év alatt ment végbe. Legutóbb 1986-ban Spanyolország és Portugália csatlakozott az EGK-hoz, amely ezáltal nemcsak nagyobb, hanem sokkal heterogénebb is lett. A regionális különbségek fokozódását jelzi - többek között -, hogy e két országban jóval alacsonyabb (25-50\%-al) az egy fôre esổ GDP, kétszer nagyobb a munkanélküliség. A térbeli egyenlôttlenségek idốben is módosulnak, míg a hatvanas években a területi eltérések mérséklôdése tapasztalható a tagországok és az egyes régiók között, addig az 1970-es évtizedtôl, fóleg a munkanélküliek számában, erôsödésük figyelhetố meg. A legsúlyosabb helyzetben a periférikus fekvésû déli és nyugati régiók, illetve országok vannak. A feszültségek enyhítése érdekében a legsürgốsebb teendố az egységes belsô piac megteremtése, és új munkahelyeket biztosító beruházások megvalósítása.

A regionális politika összetevóiben - a politikában, a társadalomban, a gazdaságban, a technológiában - bekövetkezett markáns átalakulások alaposan megváltoztatták a vele szemben támasztott elvárásokat is. Bemutatásukra Allen munkatársaival együtt vállalkozott. A regionális politikával szemben támasztott legfontosabb követelmény, hogy összhangba kerüljön a gyorsan változó körülményekkel, amelyben jelenleg és a jövôben is mûködik.

A harmadik témakörhöz öt elổadás anyaga kapcsolódik. Az ír származású Drudy a falusi régiók fejlesztésében felmerülổ problémákat és prioritásokat tárja az olvasó elé. Az elmúlt évtizedekben a Közös Piac falusi régióiban mélyreható demográfiai és mezôgazdasági átalakulás ment végbe. Számottevôen fogyott lakosságuk, részben az erôteljes elvándorlás miatt. Kedvezốtlenebb lett a helyben maradók korstruktúrája és gazdasági aktivitása. Amíg 1950-ben közel 24 millió ember dolgozott a primer szektorban, addig 1982-ben már csak harmađuk. Ugyanezen idố alatt folyamatosan csökkent a mûvelt földek mennyisége is. Mindezek a gondok, problémák - bár nagyon fontosak - csak töredékét képezik a regionális politikának. Egyre nyilvánvalóbbá válik, hogy nincsenek egyedüli, egyszerú megoldások: a falusi régióknak sokkal jobban kell saját erôforrásaikra (a földre, a vízre, az erdóre, a természeti szépségekre) építeni, és afelé kell elmozdulniuk, hogy az ezekre irányuló elképzeléseiket egy átfogó fejlesztési stratégiában foglalják össze.

Murray és Hart szintén az integrált falusi fejlesztés (Integrated Rural Development) mellett foglalnak állást a problémás falusi területek hatékony átalakítása érdekében. Példaként az észak-ír Tyrone megyében tapasztaltakat hozzák fel. Ez a térség egyike a legtöbb nehézséggel küszködổ falusi régióknak. A fölemelkedést elốsegítõ integrált fejlesztési program kidolgozásánál három alapelvet tartottak szem elốtt. Az elsố (az egymásrautaltság elve) a helyi politikai irányvonalak és a megye egészére vonatkozó politi- 
kai elképzelések közötti összhangra, kölcsönkapcsolatra utal. A második (az egyediség elve) azt jelzi, hogy a megyén belül sem azonosak az adottságok, ezért mindenkor tekintettel kell lenni a helyi sajátosságokra. A harmadik (a magában foglaltság elve) azt a felismerést tükrözi, amely szerint ahhoz, hogy a megújhodó helyi gazdaság hosszú idổn át fenn tudjon maradni, nélkülözhetetlen a megyén belüli erôforrásokból való táplálkozás.

Nagyon akłuális témát választott kutatása tárgyául Österland. Azt kísérli meg ugyanis, hogy hazája egyik depressziós térségében, a brémai régióban, felmérje a hajógyárak bezárásának a foglal koztatottságra és a helyi munkaerôpiacra gyakorolt drámai hatásait. A súlyos helyzet megoldásához egyeztetett helyi és kormányzati ellenintézkedések egyformán kellenek. Fontosnak véli, hogy az ilyen ,,posztindusztriális" vidékeken ne csak az állások létesítését, hanem a munkaerốt is támogassák. Tegyék lehetôvé számára új szakmák megszerzését, nagyobb tudásszint elérését, vállalkozói képességének kibontakozását.

Az utolsó két kisebb lélegzetũ írás a helyi gazdasági fejlesztés lehetôségeit vitatja meg. Az utóbbi években mind a politika-készítôk, mind a tudósok növekvố érdeklôdést tanúsítottak ez iránt.
Roberts a helyi regionális politika feladatainak megvalósításában az egyre nagyobb jelentốséggel bíró helyi közösségeknek tulajdonítja a legdöntốbb szerepet. Kifejti, hogy az a kölcsönhatás, amely meg kell legyen a különbözố intézményi és térbeli szintek között, lehet a regionális politika jövổbeni formájának és tartalmának tényleges alkotója.

Courlet francia példákkal igazolja, hogy a jelenlegi átstrukturálódási tendenciák a kisebb vállalatok létesítése irányába hatnak, mert ezek jobban be tudnak illeszkedni a helyi gazdasági szerkezetbe, és ezáltal az önfenntartó növekedés magjaivá válhatnak. Ezek a trendek azonban épp hogy csak felszínre kerültek, így pontos megítélésükhöz a késốbbiekben újabb és részletesebb vizsgálatok szükségesek.

A könyv minden egyes fejezetét gazdag irodalmi utalás egészíti ki, néhány ábra és táblázat teszi még teljesebbé.

Mivel napjainkra nálunk is válaszúthoz érkezett a terület- és településfejlesztési politika, úgy gondolom, hogy a nyugati tapasztalatokat, tendenciákat vázoló tanulmánykötet hasznos segítséget nyújthat a reformmunkálatokban résztvevố szakembereknek. 